\title{
Some Heavy Metals Concentration in Water, Muscles and Gills of Tilapia Niloticus as Biological Indicator of Manzala Lake Pollution
}

Hussien. M. EL-Shafei*

Genral Authority for Fish Resource Development, Damietta, Egypt

\begin{abstract}
Environmental pollution is a worldwide problem, heavy metals belonging to the most important pollutants. The progress of industries has lead to increased emission of pollutants into ecosystems. Manzala Lake is one of the most important aqua systems, which receives effluents discharges from heavily industrialized and highly populated settlements. Metals tend to accumulate in water and move up through the food chain. So, studies to ascertain the level of heavy metals in environment and determine potentially hazardous levels for human are necessary. In this study heavy metal $(\mathrm{Pb}, \mathrm{Cd}, \mathrm{Fe}, \mathrm{Cu}$, and $\mathrm{Zn}$ ) were determined in different tissues (muscle, gill) of Tilapia nilotica from the south part of Manzala lake (Egypt) to assess the lake water pollution with those toxic metals. The range of Fe was $(0.16-0.54 \mu \mathrm{g} / \mathrm{L})$ in water from sampling sites, with no significant difference between the three sites, while, the level was $(0.066-1.13 \mu \mathrm{g} / \mathrm{g})$ in muscle and fish gills. The level of $\mathrm{Zn}$ was $(0.08-0.26 \mu \mathrm{g} / \mathrm{g})$ in muscle and fish gills, but longterm disposal of wastewater into the lake resulted in high level of $\mathrm{Zn}$ and $\mathrm{Cu}$ in the tissues and gills of the fish. The concentration of lead was $(0.05-0.31 \mu \mathrm{g} / \mathrm{L})$ in water with the highest level in site 3 , the discharge point of industrial effluents and (0.09-0.46 ug/g) in muscle and fish gills. The levels of $\mathrm{Pb}$ in this study were higher than the maximum permissible limits (FAO, UNEP, FEPA, WHO and ECR. no 2360/ 2007) for human consumption. In conclusion, the levels of heavy metals observed in the fish and water samples can be considered as a serious matter. More safe and economic methods for the elimination of heavy metals from contaminated waters are needed and continuous assessment of the level of pollution of the lake waters and fish with heavy metals is also necessary. Safe disposals of domestic sewage and industrial effluents as well as enforcement of laws enacted to protect our environment are therefore advocated.
\end{abstract}

Keywords: Heavy Metal; Tissue; Gill; Manzala lake; Tilapia nilotica; Pollution

\section{Introduction}

Environmental pollution is a worldwide problem, heavy metals belonging to the most important pollutants. The progress of industries has led to increased emission of pollutants into ecosystems. Manzala Lake is one of the most important aqua systems, which receives disposal of industrial chemicals from many drains (such as Bahr ElBakar) and agricultural pollutions (from Bahr Hadose). In addition, it was contaminated by Cairo and Delta sewage drainage system [1]. Metals tend to accumulate in water and move up through the food chain. So, studies to ascertain the level of heavy metals in environment and determine potentially hazardous levels for human are necessary. It is well known that this metal easily accumulates in fish tissues such as bones, gills, kidneys, liver, and scales [2]. Heavy metal ions do not degrade into harmless end products and will be toxic to many life forms [3]. Due to their toxicity and accumulation in biota, determination the levels of heavy metals in commercial fish species have received considerable attention in different countries [4]. There has been an increasing interest in the utilization of fishes as bio-indicators of the integrity of aquatic environmental systems in recent years [5]. Fish lie at the top of the aquatic food chain and may concentrate large amounts of some metals from the water. Heavy metals enter the body of fish through the skin or gills via the dissolved phase and through the digestive tract via the food [6-8]. Because waters generally have low heavy metals levels, even when high concentrations are found on the bottom, food is a significant source of these elements for fish $[9,10]$. The concentration of heavy metal were found to be higher in the liver, kidneys and gills than in the gonad and muscle tissues in some fish species $[12,13]$ and the concentrations in the tissue of freshwater fish vary considerably among different studies. Therefore, the aim of the present study was to investigate the bioaccumulation levels of the heavy metals: Lead $(\mathrm{Pb})$, Cadmium $(\mathrm{Cd})$, Iron $(\mathrm{Fe})$, Copper $(\mathrm{Cu})$, and Zinc ( $\mathrm{Zn})$, and their accumulation in the muscle tissues and gills of the commercially important and common, eatable fishes (Tilapia niloticus) that are found in Manzala lake.

\section{Materials and Methods}

\section{Description of site}

Lake Manzala is the largest of the four brackish coastal lakes fringing the Nile Delta. The lake lies between 31' 45, 32' $15 \mathrm{E}$ and 31' 00, 31' $35 \mathrm{~N}$. It is bordered by Suez Canal from east, Damietta branch of Nile from west and Mediterranean Sea from north Figure 1. The lake connected to the Mediterranean Sea via fiver outlets, permitting exchange the water and biota between the lake and the sea. These outlets are (EL-soufara, El-Boughdady) at Damietta, El-Gamil , new El-Gamil , and Cannal ELEtisaal ) at Port Said. The study area lie at the southern part of the lake which far from the sea and the coastal area, so the sea water cannot reach it and make circulation of the water between these of the lake and the sea to remove pollution.

\section{Sample collection}

1- Water samples were collected from a depth $40 \mathrm{~cm}$ from three

*Corresponding author: Hussien. M. EL-Shafei, Genral Authority for Fish Resource Development, Damietta, Egypt, Tel: 963934341385; E-mail: elshafei.hussien@yahoo.com

Received May 08, 2015; Accepted May 26, 2015; Published June 30, 2015

Citation: Shafei HMEL (2015) Some Heavy Metals Concentration in Water, Muscles and Gills of Tilapia Niloticus as Biological Indicator of Manzala Lake Pollution. J Aquac Res Development 6: 358. doi:10.4172/2155-9546.1000358

Copyright: ( 2015 Shafei HMEL. This is an open-access article distributed under the terms of the Creative Commons Attribution License, which permits unrestricted use, distribution, and reproduction in any medium, provided the original author and source are credited. 


\section{Con. of Heavy Metal in water ug/l in the studied} gp

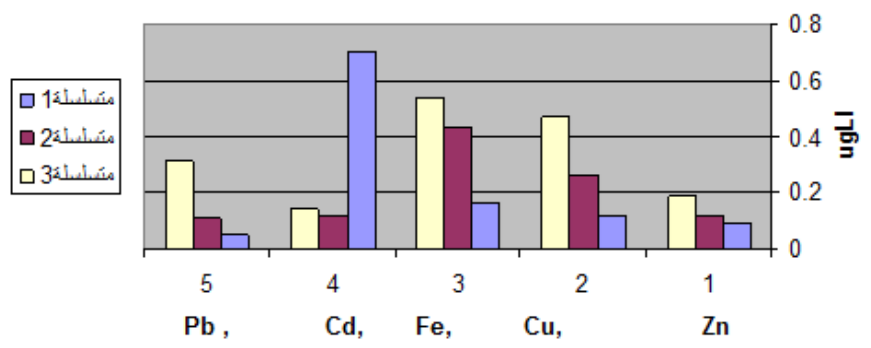

Figure 1: Concentration of heavy metal water of the studied GPS.

\begin{tabular}{|c|c|c|c|c|c|}
\hline Site Prameter & $\mathrm{Pb}$ & $\mathrm{Cd}$ & $\mathrm{Fe}$ & $\mathrm{Cu}$ & $\mathrm{Zn}$ \\
\hline Site: 1 & 0.05 & 0.07 & 0.16 & 0.12 & 0.091 \\
\hline Site: 2 & 0.11 & 0.12 & 0.34 & 0.26 & 0.12 \\
\hline Site: 3 & 0.31 & 0.14 & 0.54 & 0.47 & 0.19 \\
\hline
\end{tabular}

Site 1: AL-atwey Damietta, Site 2: AL-Gmalia Dakahlyi and Site 3: Materyia Dakahlia.

Table 1: Concentration of heavy metal in $\mu \mathrm{g} / \mathrm{L}$ in water in the studied group.

sites (one sample from each) using automated water sampler (21 cc capacity) and stored in amber-colored polyethylene bottles $(1 \mathrm{~L})$ prewashed with $1(\mathrm{~N}) \mathrm{HNO}_{3}$ and de ionized water. To prevent further oxidation or any fungal growth $5 \mathrm{~mL}$ concentrated $\mathrm{HNO}_{3}$ was added to the sampled water.

2- Forty five (45) adult fish sample fifteen (15) each of Tilapia nilotica was procured from fishermen around the lake from three different sites. AL-Atwey Damietta site (1), AL-Gamalia Dakahlia site (2) and Materyia Dakahlia sites (3). These fish species were put in sterile polythene bags and taken in icebox to the laboratory where they were washed with running tap water to remove dirt. All the fish samples were then separately stored inside deep freezer at about $-10^{\circ} \mathrm{C}$ and were allowed to thaw, scales were removed and washed with running water before dissected with sterile scissors to remove gills, operculum, vertebrae, heart, muscles and kidney. These were transferred into sterile sample bottles, labeled and kept for digestion and analysis of heavy metals.

\section{Samples treatment and analysis}

1- Fish muscle tissues and gills were taken from each specimen after removing the scales and skin, and each was cut into small pieces, ground well thoroughly to achieve homogeneity and used to prepare the ash solution using Inductively Coupled Plasma Emission Spectroscopy (plasma 400 emssion spectrophotometer, perkin Elmer, Norwalk Connecticut, USA) ICP-ES analysis. About $4 \mathrm{~g}$ of the each sample were kept in muffle furnace on a hot plate at $550^{\circ} \mathrm{C}$ for 3 hours to obtain the ash. Ash was dissolved in $10 \mathrm{ml}$ of $20 \% \mathrm{HCl}$ then filtered in a $100 \mathrm{ml}$ volumetric flask and the volume was completed with distilled water to $50 \mathrm{ml}$. Each ash solution was analyzed for heavy metals), Lead $(\mathrm{Pb})$, Cadmium $(\mathrm{Cd})$, Iron and $(\mathrm{Fe})$, Copper $(\mathrm{Cu})$, and Zinc $(\mathrm{Zn})$ using inductively coupled plasma- optical emission spectrometry ICP-OES.

2- Water samples were not subjected to any further treatment and were also analyzed for the same heavy metals using Inductively Coupled Plasma Emission Spectroscopy( plasma 400 emssion spectrophotometer, perkin Elmer, Norwalk Connecticut, USA) ICP-ES. The concentration of each metal was detected in a triplicate ash samples of fish muscles and gills as well as water samples, and recorded in ppm $(\mu \mathrm{g} / \mathrm{g}, \mu \mathrm{g} / \mathrm{L})$ respectively according to APHA [13].

\section{Statistical analysis}

Results are presented as means $\mathrm{M} \pm \mathrm{SE}$, where $\mathrm{n}$ equals the number of fish samples from which tissues and gill were isolated. Results from all the specimens were compared using ANOVA and $\mathrm{P}<0.05$ was considered to indicate statistical significance. Means of significant differences were separated using Duncan's Multiple Range Test.

\section{Results and Discussion}

\section{Concentration of heavy metals in water samples}

The water samples at each sampling sites were also analyzed by using ICP-ES. The concentration of $\mathrm{Pb}$ and Fe was very high in all sampling sites Table 1 . The range of Fe was $(0.16-0.54 \mu \mathrm{g} / \mathrm{l})$ in water sample with no significant difference between the three sampling sites,

These results were agreed with that reported by Abd elhamid and El-Zareef [14] they gave mean value ranged from $(0.10-0.43)$ $\mathrm{mg} / \mathrm{L}$ in El-Manzala lake's water. And disagreed with that reported by Mohammed [15] who gave average values for Fe range (0.35-1.33) $\mathrm{mg} / \mathrm{l}$ in water collected from different locations of Egypt. The concentration of $\mathrm{Cd}$ was a pit higher while the range of $\mathrm{Pb}$ was $(0.05-0.31 \mu \mathrm{g} / \mathrm{l})$ in water with increased concentration in site 3 , the discharge point of the treated waste-water at Baher EL-Baker drain. The high levels of Cd and $\mathrm{Pb}$ in water can be attributed to industrial and agricultural discharge [16]. The high level of $\mathrm{Pb}$ in water of Lake Manzala and Borollus could be attributed to the industrial and agricultural discharge as well as from spill of leaded petrol from fishing boats and dust which holds a huge amount of lead from the combustion of petrol in automobile cars [17]. The high level of $\mathrm{Pb}$ in water of northern delta Lakes can be attributed to heavily traveled roads that run along the Lakes. Higher levels of $\mathrm{Pb}$ often occur in water bodies near highways and large cities due to high gasoline combustion [18].

The concentration $\mathrm{Zn}$ and $\mathrm{Cu}$ was very low and below the detection limit in all sampling sites. However, Zyadah [19] reported higher zinc concentrations in water samples ranged from (9.47-12.3 ppm) and (0.94$2.32 \mathrm{ppm}$ ) in El-Manzala lake's. While, Abdelhamid and El-Zareef [14] recorded that zinc concentrations ranged from $(0.01-0.09 \mathrm{mg} / \mathrm{L})$ in ElManzala lake's water. Mohammed et al. [11] gave average values ranged from $(0.096-0.12 \mathrm{mg} / \mathrm{L})$ in Lake Qarun. The distribution patterns of $\mathrm{Cu}$ and $\mathrm{Zn}$ in the Lake water increased in hot seasons (spring and summer) which may be attributed to the release of heavy metals from sediments to the overlying water under the effect of both high temperature and fermentation process resulted from decomposition of organic matter [20]. These levels are higher than the permissible limits recommended by USEPA and the Egyptian laws [21]. This may be attributed to the huge amounts of raw sewage, agricultural and industrial wastewater discharged into the Lake [22]. On the other hand, $\mathrm{Zn}$ and $\mathrm{Cu}$ values are within the allowable limits according to USEPA.

Lead was detected in the three sites $(0.054-0.44 \mu \mathrm{g} / \mathrm{g})$ in mussel and gill with the highest level in sites $(2,3)$, the discharge point of industrial and sewage-treated water effluents. The above data indicated the order of heavy metals accumulation in fish muscles and gills was $\mathrm{Pb}>\mathrm{Fe}>\mathrm{Zn}>\mathrm{Cu}>\mathrm{Cd}$ for samples of fish from both sites of collection, while the concentrations of heavy metals in the water collected from three sites had the order $\mathrm{Fe}>\mathrm{Cu}>\mathrm{Pb}>\mathrm{Zn}>\mathrm{Cd}$. The trend of accumulation suggested deposition was maximum for lead and iron, and minimum for cadmium in the muscles and gills of fish samples Figure 2. In 
water samples, the concentration of $\mathrm{Pb}$ and $\mathrm{Fe}$ was very high in Sites $(2,3)$ where effluent from different sources are discharged, then the level came down at Site (1) which far from the point of industrial and sewage-treated water. This situation explains why the concentrations of these metals were high at Sites (2,3), and consequently, their levels in the water increase at Sites $(2,3)$, which is released into the lake. The water condition was also very muddy caused by the effluent discharge into the water.

This result was in agreement of [23]. The concentrations of heavy metals including Iron, Zinc, Copper, Manganese, Cadmium and Lead $(\mathrm{Fe}, \mathrm{Zn}, \mathrm{Cu}, \mathrm{Mn}, \mathrm{Cd}$ and $\mathrm{Pb}$ ) in water and sediments in northern Delta Lakes (Edku, Borollus and Manzala) and their accumulation in Nile tilapia (Oreochromis niloticus) organs (muscle, gills and liver) were investigated.

Water, sediments and fish organs from Lake Manzala showed greater concentrations of most of the studied metals than those from Lake Edku and Lake Borollus. Fe, $\mathrm{Mn}, \mathrm{Cd}$ and $\mathrm{Pb}$ (in Lake Manzala) and $\mathrm{Mn}$ and $\mathrm{Pb}$ in Lake Borollus recorded levels above the international permissible limits in water. Gills and Liver of O. niloticus contained the highest concentration of most the detected heavy metals, while muscles appeared to be the last preferred site for the bioaccumulation

\section{Con. of Heavy Meta in fish Tissue of the studied} gp

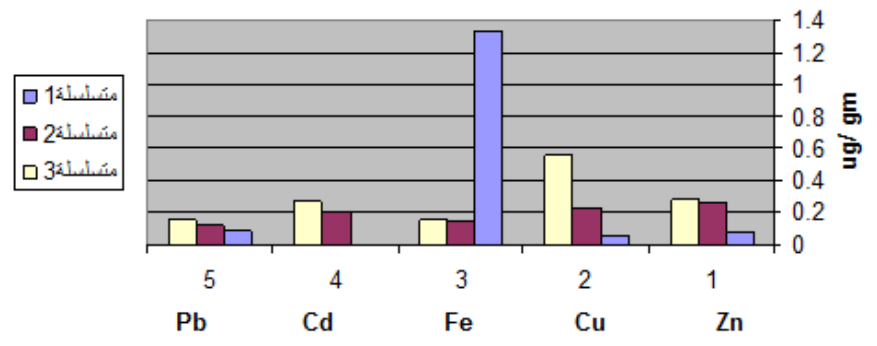

Figure 2: Concentration of heavy metal in fish tissue of the studied GPS. of metals. The edible part of O. niloticus showed higher levels of $\mathrm{Cd}$ (in Lake Edku and Manzala) and Pb (in Lake Manzala). Zyadah [19] reported that the cadmium levels in El-Manzala lake's water ranged between 0.036 and $0.15 \mathrm{mg} / \mathrm{L}$. While El-Safy and Al-Ghannam [24] found that the concentration of cadmium in the same lake's water ranged between 0.009-0.013 ppm. Moreover, El-Mezein [25] found that cadmium levels in El-Manzala lake's water took a range of 7.6-766 ppb and 10-132 ppb. On the other hand, Salbu and Steinnes [26] mentioned that Scandinavian Small Headwater lake's contained 0.004-0.54 ppb cadmium. While very low concentration were recoded in Dart's lake's water (in New York), which contained 0.7 ppb cadmium [27].

\section{Concentrations of heavy metals in fish samples}

The concentrations of heavy metals $(\mathrm{Pb}, \mathrm{Cd}, \mathrm{Fe}, \mathrm{Cu}$, and $\mathrm{Zn})$ determined in fish muscle and gills at the three sampling sites are given in Tables 2. The highest concentration of the heavy metal in muscle and gills was recorded for $\mathrm{Pb}$, followed by $\mathrm{Fe}, \mathrm{Zn}, \mathrm{Cu}$, and $\mathrm{Cd}$ where $\mathrm{Pb}$ and Fe recorded higher concentrations in the muscles compared to the gills of fish samples collected from all sites.

Although some metals such as $\mathrm{Zn}$ and $\mathrm{Cu}$ were high in the tissues and gills of the fish, they are very low and below the detected limits in the water from where the fish samples were collected. This however is in agreement with a study in Turkey and Malaysia, where the concentration of heavy metals in fish was high even the concentration of heavy metals in the water was low [28]. El-Mezein [25] gave average value ranged from 10.82 to 19.48 and 16.2 to $18.33 \mathrm{mg} / \mathrm{kg}$ dry weight for lead in fish muscles collected from El-Manzalah lake. Ayotunde and Offen [29] found a level of ( 0.02 to $0.04 \mathrm{mg} / \mathrm{kg})$ of lead in muscle tissues of some species of freshwater fish from Cross River in Nigeria and Oladimeji and Offen [30] noticed in O. niloticus, that the gills consistently accumulated higher amount of lead as lead nitrate. The biological effects of sub lethal concentrations of lead include delayed embryonic development, suppressed reproduction, and inhibition of growth, increased mucous formation, neurological problems, enzyme inhalation and kidney dysfunction. Because lead crosses the bloodbrain barrier, it can cause various detrimental effects to the body

\begin{tabular}{|c|c|c|c|c|c|c|c|}
\hline Site & $\mathrm{Pb}$ & Cd & $\mathrm{Fe}$ & $\mathrm{Cu}$ & $\mathrm{Zn}$ & Weight & Length \\
\hline Site: 1 & & & & & & & \\
\hline Tissue & $0.09 \pm 0.025$ & $0.0048 \pm 0.02$ & $1.13 \pm 0.02$ & $0.060 \pm 0.02$ & $0.08 \pm 0.2$ & $110.5 \pm 0.0$ & $14.3 \pm 0.02$ \\
\hline Site: 2 & & & & & & & \\
\hline Tissue & $0.16 \pm 0.02$ & $0.27 \pm 0.03$ & 0.16 & $0.24 \pm 0.021$ & $0.26 \pm 0.03$ & $101.2 \pm 0.03$ & $15.8 \pm 0.02$ \\
\hline Site: 3 & & & & & & & \\
\hline Tissue & $0.446 \pm 0.02$ & $0.048 \pm 0.025$ & $0.254 \pm 0.02$ & $0.112 \pm 0.03$ & $0.17 \pm 0.02$ & $123.73 \pm 0.025$ & $14.2 \pm 0.03$ \\
\hline
\end{tabular}

Site 1: AL-atwey Damietta, Site 2: AL-Gmalia Dakahlyi and Site 3: Materyia Dakahlia.

Table 2: Concentration of heavy metal in ug/kg in Tilapia niloticus fish ( tissue), Weight in gm and Length in $\mathrm{cm}$ in the studied group.

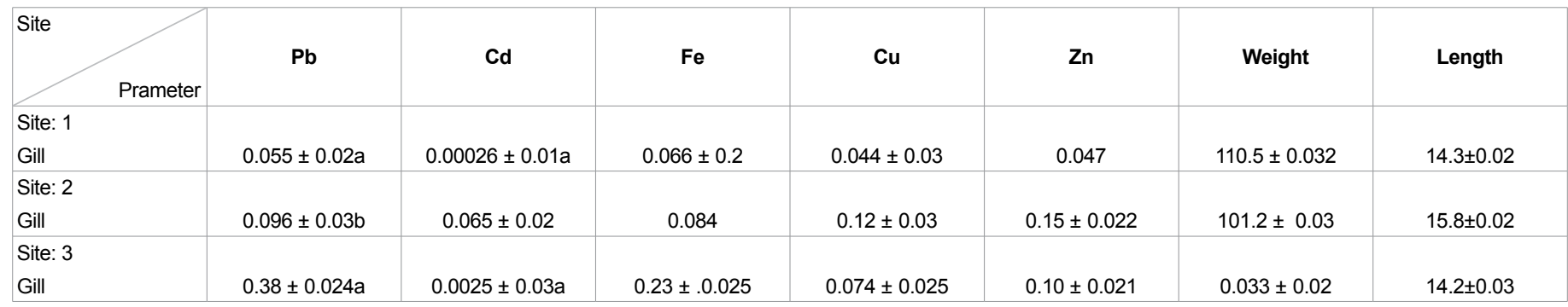

Site 1: AL-atwey Damietta, Site 2: AL-Gmalia Dakahlyi and Site 3: Materyia Dakahlia.

Table 3: Concentration of heavy metal in ug/kg in Tilapia niloticus fish ( tissue and gill), Weight in gm and Length in $\mathrm{cm}$ in the studied group. 
condition, health, and life of fish [31-33]. Bioaccumulation of lead in piscine tissues is a threat to humans who may absorb considerable amounts of this metal from contaminated fish. It is common knowledge that lead adversely affects the intellectual development of children, increases arterial pressure, and contributes to cardiovascular diseases in adults (EC 2001). The level of lead in muscle and gills of O. niloticus was below the $(0.5 \mu \mathrm{g} / \mathrm{g})$ limits in Tables 3. The accumulation of cadmium was higher in muscles compared to fish gills. Dural et al. [34] reported highest levels of cadmium, lead, copper, zinc and iron in the liver and gills of fish species viz. Sparus aurata, Dicentrachus labrax, Mugil cephalus and Scomberomorus cavalla. Yilmaz et al. [35] reported maximum accumulations of cadmium, cobalt and copper in the liver and gills of Leuciscus cephalus and Lepornis gibbosus, while these accumulations were least in the fish muscle. However, as could be deduced from the present study, the muscles accumulate more of these metals. The levels of $\mathrm{Pb}$ in this study were higher than the maximum permissible limits (Food and Agriculture Organization (FAO), United Nations Environment Programme ( UNEP), Federation of the European Producers of abrasives ( FEPA), World Health Organization (WHO) and the Egyptian Commission Regulation (ECR). no 2360/ 2007 ) for human consumption. Cd may unlikely be harmful to human and ecological health due to the very low total concentrations [36]. Cd is toxic elements which have no known biological function and show their carcinogenic effect on aquatic biota and humans. Cadmium is widely distributed at low levels in the environment and is not an essential element for humans, animals and plants. The European and National Drinking Water Quality Standards Maximum Residue Limit (MRL) permitted in fish is $0.3 \mu \mathrm{g} / \mathrm{g}$ for $\mathrm{Pb}$ and $0.1 \mu \mathrm{g} / \mathrm{g}$ for $\mathrm{Cd}$. The levels of lead, copper, zinc and iron in suspended particulate matter content range between $3.1-27.5 \mathrm{mg} / \mathrm{kg} ; 0.4-11.7 \mathrm{mg} / \mathrm{kg} ; 1-1.5 \mathrm{mg} /$ $\mathrm{kg} ; 1.2-1.7 \mathrm{~g} / \mathrm{kg}$, respectively. This study revealed that heavy metals

\section{Con. of Heavy Metal in Fish Gill in the studied gp}
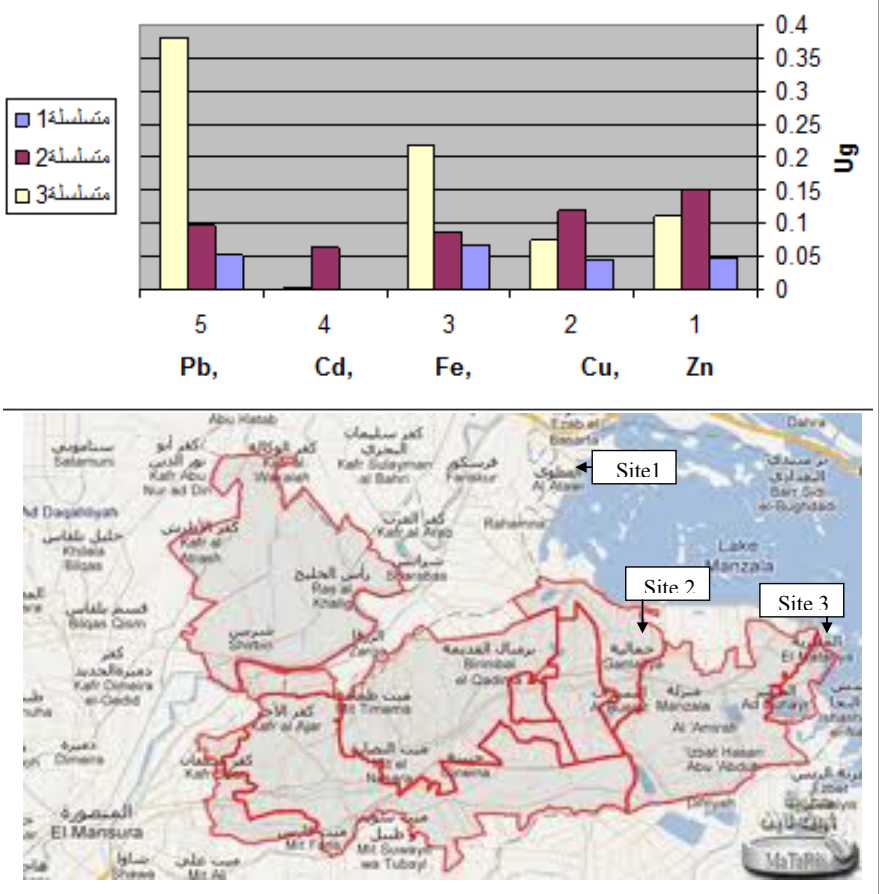

Map of Manzala lake show the three study site site.

Figure 3: Concentration of heavy metal in fish gill of the studied GPS. pollution is mainly localized in the commercial (Rades) and fishing (La Goulette) harbours and not in the yachting (Sidi Bou Said harbour) [37]. High level of $\mathrm{Cu}$ was also detected in both muscle and fish gills. For the gills samples, it may be due to the fact that freshwater fish's gills might be expected to be the primary route for the uptake of water borne pollutants. WHO reported that copper toxicity in fish is taken up directly from the water via gills and stored in the liver. Copper and zinc were the most abundant metals and ranged from 11 to $63 \mathrm{mg} / \mathrm{kg}$ and from 31 to $185 \mathrm{mg} / \mathrm{kg}$ in coral tissues, respectively. The highest concentration of each metal was measured in P. furcata tissues, with copper and mercury concentrations significantly higher in P. furcata than in A. Tenuifolia at every site Figure 3. These results suggest that $P$. furcata has a higher affinity for metal accumulation and storage than $A$. Tenuifolia [38]. Although, the concentrations of heavy metals $\mathrm{Fe}, \mathrm{Cu}$, and $\mathrm{Zn}$, determined were very low and below the detection limit, the continuous discharge from the sewage treatment into the south part of the lake might be the contributor of heavy metal accumulation and other possible pollutants in the fish samples. The high load of heavy metals is due to the presence of major sources of metal pollution, intensive human activity and discharge of municipal waste and industrial effluents map.

Our results for iron concentration in fish muscle are disagreed with Zaghloul [39] who reported that average level ranged between 10.730.6 and $8.6-21.3 \mathrm{mg} / \mathrm{kg}$ wet weight in muscle of

fish. Also our results were disagreed with those found by Abdelhamid and El-Zareef [14] they gave average percentage values ranged from 116.00 to 235.00 and 158.00 to $270.00 \mathrm{mg} / \mathrm{kg}$ dry weight of fish muscles from El-Manzala lake. Allowance zinc level (40-50 mg/ $\mathrm{kg}$ ) wet weight was report by WHO/FAO. Also, Zyadah [19] gave (40.84 $\mathrm{ppm}$ ) for fish collection from El-Manzala lake.

\section{Conclusion}

In conclusion, the levels of $\mathrm{Fe}, \mathrm{Zn}, \mathrm{Cu}, \mathrm{Pb}$ and $\mathrm{Cd}$ observed would have harmful effect on the health of the community in the study area. Heavy meals are one of the more serious pollutants in our natural environment due to their toxicity, persistence and bioaccumulation problems, thus fish species will not be safe for human consumption. Despite its extensive treatment processes for heavy metal removal from wastewater residues, heavy metals remain in the water and absorbed by fish. The concentrations of heavy metal in the tissue of freshwater fish vary considerably among different studies. Therefore, there should be a continuous assessment of pollution with metals from the mentioned sources in the lake water and other commercial lake fish, with a view to reducing the level of pollution via education and public enlightenment. Fish can be considered as an index of metal pollution in the aquatic bodies [40], Multivariate statistical techniques, such as principal component (PCA), cluster (CA), and lineal discriminant (LDA) analyses were applied for identification of the most significant variables influencing the environmental quality of water. The usefulness of the multivariate statistical techniques employed for the environmental interpretation of a limited dataset was confirmed. Alvarez and therefore, could be a useful tool to study the biological role of metals present at higher concentrations in different species of the lake fish.

\section{References}

1. Dawoud AS, Salem AH, Samah AS (2009) Clinico Pathological Studies On The Impact of Heavy Metal Pollution on Catfish In River Nile In Damieta And Dakhlaia Governorayters. Egypt J Comp Path Clinic Path 23: 37-61. 
Citation: Shafei HMEL (2015) Some Heavy Metals Concentration in Water, Muscles and Gills of Tilapia Niloticus as Biological Indicator of Manzala Lake Pollution. J Aquac Res Development 6: 358. doi:10.4172/2155-9546.1000358

2. Dallas HF, Day JA (1993) The effect of water quality variables on riverine ecosystems: a review.

3. Paulami M, Banerjee S (2012) Fate of metals in fish under variable sewage input in fish ponds. Int $\mathrm{J}$ sci Res Pub 2: 1-13.

4. Wariaghli F, Tigillimann A, El Abidi A, El Hamri H, Fekhaoui M, et al. (2013) Evaluation of the degree of heavy metals contamination in the Sebou Estuary and in Moulay Bousselham reserve. Int J Aquatic Science 4: 69-82

5. Tawari Fufeyin P, Ekaye SA (2007) Fish species as indicator of pollution in Ikpoba River, Benin City, Nigeria. Review of Fish Biology and Fisheries 17: 21-30

6. Pourang $N$ (1995) Heavy metal bioaccumulation in different tissues of two fish species with regards to their feeding habits and trophic levels. See comment in PubMed Commons below Environ Monit Assess 35: 207-219.

7. Vincent S, Ambrose T, Selvanayagam M (2002) Impact of cadmium on food utilization of the Indian major carp, Catla catla (Ham). J Environ Biol 23: 209-212.

8. Sarnowski $P$ (2003) The effect of metals on yolk sac resorption and growth of starved and fed common carp (Cyprinus carpio) larve. Acta Sc Pol Piscaria 2: 227-236.

9. Javed M, Hayat S (1996) Planctonic productivity of river water as a bio-indicator of freshwater contamination by metals. Proc Pak Cong Zool 16: 298-383.

10. Clearwater SJ, Baskin SJ, Wood CM, McDonald DG (2000) Gastrointestinal uptake and distribution of copper in rainbow trout. See comment in PubMed Commons below J Exp Biol 203: 2455-2466.

11. Mohamed AW (2005) Geochemistry and sedimentology of core sediment and influence of human activities, Quiser, Safaga and Hasiphada Harbors, Red Sea Coast, Egypt. Egyptian J Aquatic Resources 31: 92-103.

12. Sabo A, Nayaya AJ, Galadima Al (2008) Assessment of some heavy metals in water, sediment and freshwater Mudfish (Clarias gariepinus) from Rive Gongola in Yamaltu-Deba, Gombe, Nigeria. Int J Pollution and Applied Sciences 2: 6-12.

13. APHA (1998) Standard Methods for the Examination of Water and Wastewater

14. Abd ellhamid AM, EL Zareef AAM (1996) Further studies of the pollution status on the southern region of EL-Manzalah Lake.

15. Mohammed AHI (1999) Biochemical studies on the Effect of Pollution on the Fish Production in Dakhlia and Damietta.

16. Mason CF (2002) Biology of freshwater pollution.

17. Hardman DJ, Mceldowney S, Watte S (1994) Pollution, ecology and biotreatment.

18. Banat IM, Hassan ES, El-Shahawi MS, Abu-Hilal AH (1998) Post-gulf-war assessment of nutrients, heavy metal ions, hydrocarbons, and bacteria pollution levels in the United Arab Emirates coastal waters. Environ Inter 24 109-116.

19. Zayadah MAI (1995) Environmental impact assessment of pollution in lake Manzalah, and its effect on fish

20. Elewa AA, Shehata MB, AbdelSatar AM, Satar A, Ali MHH, et al. (2001) Effect ofthe drainage water on lake Qarun ecosystem, Egypt.

21. Khallaf EA, Galal M, Authman M (1998) Assessment of heavy metals pollution and their effect on Oreochromis niloticus in aquatic drainage canals. J Egypt Ger Soc Zoo 26: 39-74

22. Abdel-Moati MA, El-Sammak AA (1997) Man-made impact on the geochemistry of the Nile Delta Lakes. A study of metals concentrations in sediments. Water Air and Soil Pollution 97: 413-429.

23. Samir MS, Ibrahim MS (2008) Assessment of heavy metals pollution in water and sediment and their effect on oreochromis niloticus in the northern delta lakes, Egypt.
24. El-Safy MK, ALGhannam ML (1996) Studies on some heavy metal pollutants in fish of Al- Manzalah Lake.

25. El- Mezein AM (1997) Fish production and pollution.

26. Salbu B, Steinnes E (1995) Trace Elements in Natural Waters.

27. Stripp RA, Heit M, Bogen DC, Bidanset J, Trombetta L (1990) Trace element accumulation in the tissue of fish from lakes with different $\mathrm{pH}$ values. Water Air and Soil Pollution 51: 75-87.

28. Ismaniza I, Saleh IM (2012) Analysis of heavy metals in water and fish (Tilapia sp.) samples from Tasik Mutiara, Puchong. The Malysian J Analytical Sciences 16: $346-352$

29. Ayotunde EO, Offen BO, Ada FB (2012) Heavy metals profile of water, sediment and freshwater catfish Chrysichthys nigrodigtalus (Siluriformes, Bagridae) of Cross River, Nigeria. Rev Biol Trop 60: 1289-1301

30. Oladimeji AA, Offen BO (1989) Toxicity of lead to Clarias lazera, Oreochromis niloticus, Chironomus tantans and Benacus sp. Water, Air and Soil Pollution 44: 191-201.

31. Hodson PV, Blunt BR, Spy DJ (1978) Chronic toxicity of water-borne and dietary lead to rainbow trout (Salmo gairdneri) in Lake Ontario water. Water Res 12: 869-878.

32. Needleman HL, Bellinger D (1991) The health effects of low level exposure to lead. See comment in PubMed Commons below Annu Rev Public Health 12 $111-140$

33. Rabitto IS, Alves Costa JR, Silva de Assis HC, Pelletier EE, Akaishi FM, et al. (2005) Effects of dietary $\mathrm{Pb}(\mathrm{II})$ and tributyltin on neotropical fish, Hoplias malabaricus: histopathological and biochemical findings. Ecotoxicol Environ Saf 60: 147-156.

34. Dural M, Goksu MZ, Ozak AA ( 2007) Investigation of heavy metal levels in economically important fish species captured from the Tuzla Lagoon. Food Chemistry 102: 415-421

35. Yilmaz F, Ozdemir N, Demirak A, Tuna A (2007) Heavy metal levels in two fish species Leuciscus cephalus and Lepomis gibbosus. Food Chemistry 100 830-835.

36. Zhuang Wen, Xuelu G (2014)Integrated Assessment of Heavy Metal Pollution in the Surface Sediments of the Laizhou Bay and the Coastal Waters of the Zhangzi Island, China: Comparison among Typical Marine Sediment Quality Indices PLOS ONE 9.

37. Chouba L, Mzoughi N (2013) Assessment of heavy metals in sediment and in suspended particles affected by multiple anthropogenic contributions in harbours. Int J Environ Sci Tech 10: 779-788.

38. Berry K, Janina S, Olaf D, Ulrich S (2013) Wild, Christian; Leinfelder, Reinhold , Sources and spatial distribution of heavy metals in scleractinian coral tissues and sediments from the Bocas del Toro Archipelago.

39. Zaghloul KH (1997) Studies on the effect of water pollution along different sites of the River Nile on the survival and production of some freshwater fishes.

40. Anim AK, Ahialey EK, Duodu GO, Ackah M, Bentil NO (2011) Accumulation profile of heavy metals in fish samples from Nsawam, along the Densu River Ghana. Res J Environment and Earth Science 3: 56-60 